\title{
Uma verdadeira máscara não esconde, ela torna visível
}

\section{As primeiras máscaras: máscaras de escultor}

Béatrice Picon-Vallin: Antes de fabricar máscaras você fez uma viagem que o levou a vários países. Foi para descobrir outras formas de teatro?

Erhard Stiefel: Eu fiz uma viagem de volta ao mundo entre 1960 e 1961, que me levou à África, à Índia, ao Vietnã e ao Japão. Não era tanto para ver teatro, mas para descobrir o mundo. Quando estive pela primeira vez no Japão, creio não ter assistido a

\footnotetext{
${ }^{1} \mathrm{O}$ encontro que originou essa entrevista ocorreu na sede do Théâtre du Soleil, na Cartoucherie de Vincennes, na França, em 29 de fevereiro de 2004.

Béatrice Picon-Vallin é diretora de pesquisas no CNRS - Centro Nacional de Pesquisa Cientifica. Até 2008, ela foi professora de História do Teatro no CNSAD - Conservatório Nacional Superior de Arte Dramática. Ela dirige três coleções dedicadas à Artes do Espetáculo : a thXX, na editora l'Age d'Homme, Mettre en scène, na Actes SudPapiers e Artes do Espetáculo, nas Edições do CNRS. Especialista do teatro russo e de Vsevolod Meyerhold, o qual ela traduziu as obras completas. Suas linhas de pesquisas principais são: a encenação e o jogo do ator na Europa; as problemáticas relacionadas à formação do ator e do diretor; as relações entre o teatro; as outras artes e novas tecnologias e a relação entre o teatro ocidental e o teatro asiático.
}

Erhard Stiefel é escultor e criador de máscaras. É também grande conhecedor, apreciador e colecionador de máscaras clássicas japonesas, balinesas, italianas e africanas. Ele estudou desenho e pintura nas Artes Aplicadas de Zurique e se formou na Escola de Belas Artes de Paris e na Escola Jacques Lecoq. Desde 1967, ele colabora regularmente com o Théâtre du Soleil em diversas de suas criações e já realizou máscaras para diversos diretores, tais como Maurice Béjart, Antoine Vitez, Philippe Avron, Yves Hunstad, Jean-Pierre Vincent, Jean-Louis Thamin, Christian Schiaretti, Charles Tordjman, Alfredo Arias e Tim Robbins. A partir de 1997, ele é professor-conferencista na Escola do Louvre e em 2000 recebeu do Ministério da Cultura e Comunicação francês o título de "Maître d'Art", em reconhecimento à excelência de seu trabalho. Suas viagens e sua relação com o teatro asiático é intensa e influenciou profundamente seu trabalho.

Ariane Mnouchkine é uma das fundadoras do Théâtre du Soleil e desde então dirige esta que é uma das mais importantes companhias de teatro da França e do mundo. Cada novo projeto é concebido com uma aventura artística coletiva, uma "exploração visionária". O teatro asiático foi uma grande fonte de inspiração nos processos de criação da companhia e durante muito tempo a máscara foi uma ferramenta de base, uma referência constante, um guia de trabalho. Dentre suas principais criações estão: Os Náufragos da Louca Esperança (2010); Les Ephémères (2006); Le Dernier Caravansérail (2003); Tambours sur la digue (1999); Et soudain des nuits d'éveil (1997); O Tartufo (1995); A Oréstia (1990-92); , A História terrivel mas inacabada de Norodom Sihanouk, o rei do Camboja (1985); a trilogia Shakespeare (1981 - 1984); Mephisto (1979); L'Age d'Or (1975); 1789 (1970); Os Clowns (1969); Sonho de uma noite de verão (1968); A Cozinha (1967). 
nenhum espetáculo de Nô, nem de Kabuki. Na época eu estava mais interessado pela pintura e escultura do que pelo teatro.

B. P.-V.: Como nasceu o seu gosto pelo teatro?

E. S.: Minha mãe era bailarina e eu aprendi alguns fundamentos do ballet clássico. Aos dez anos vi "A Flauta Mágica" de Mozart e fiquei muito impressionado pelo fato de ser possível recriar uma floresta em cena. Sempre tive vontade de fazer cenários de teatro. Ainda hoje, guardo uma forte lembrança de outros espetáculos como os do Bread and Puppets, Arlequin servidor de dois amores, encenado por Giorgio Strelher com Marcello Moretti, ou Ingrid Bergman interpretando Hedda Gabler. Meu interesse pelo teatro veio muito progressivamente. No início, a máscara era uma arte solitária para mim. A ideia de trabalhar com um grupo me dava medo.

B. P.-V.: Por quê você fez os cursos de teatro da Escola de Jacques Lecoq?

E. S.: Eu tinha feito a Escola de Belas Artes e me sentia atraído pelas artes visuais, pela mímica. Ao meu redor, as pessoas diziam que eu poderia ser ator. Fui à Escola Jacques Lecoq porque ela não formava unicamente pessoas que queriam ser atores. Eu tinha um sotaque horrível. Fazer um teatro mudo era também uma solução para esse problema.

B. P.-V.: Foi onde você descobriu as máscaras de teatro?

E. S.: Eu já havia me interessado por máscaras anteriormente, mas foi na Escola que descobri o trabalho de Amleto Sartori. Foi um choque para mim, pois cada uma de suas máscaras era muito forte.

B. P.-V.: Você teve esse primeiro choque ao vê-las ou ao utilizá-las?

E. S.: Primeiramente, ao vê-las. E ao trabalhar com a máscara neutra, me dei conta de que não queria ser ator e de que eu amava, sobretudo, ver os outros atuando com as máscaras.

B. P.-V.: Quando você se direcionou para a fabricação de máscaras?

E. S.: Antes de fazer a Escola de Lecoq, eu já havia feito algumas máscaras "de escultor" para um espetáculo de dança do Théâtre Recamier. Depois, comecei a procurar documentos e visitar museus. Fui à Itália em 1962, ou 63, e fiquei bastante surpreso ao encontrar somente alguns poucos documentos iconográficos. Pude ver apenas três ou quatro máscaras, em péssimo estado, completamente deformadas. Fui à Suíça também. É claro que existem livros antigos sobre a commedia dell'arte - o mais velho dentre eles data do século XVI. E existe também o livro de Gherardi que data do século XVIII, mas foram redigidos sem ilustrações. Nas raras gravuras que podemos ver, como as de 
Receuil Fossard (século XVI) por exemplo, as máscaras são apenas manchas pretas. Por quê as máscaras foram tão pouco reproduzidas e mal conservadas? Sem dúvida, porque elas eram feitas de material perecível, como o papel ou o couro maleável. E talvez esta arte tenha deixado de existir em um determinado momento. Na Ópera de Paris existem duas máscaras do século XVIII, a partir das quais Amleto Sartori fez reproduções para Jacques Lecoq. Esse último tentou trabalhar com elas, mas essas máscaras não "funcionaram" como ele esperava. Que eu saiba, ninguém, nos anos sessenta, fabricava máscaras. Eu não queria copiá-los. Queria criar, eu mesmo, reinventar, partindo de rostos e os transportando. Desse modo comecei uma pesquisa que prossigo até hoje. Na época, eu me interessava, especialmente, pela mímica, presente no trabalho de Pierre Byland, de Sami Molcho, na Áustria, do clown Dimitri na Suíça, para quem fiz algumas máscaras. Contudo, eu me interessei inicialmente pela máscara, como um artista plástico e não como homem de teatro.

B. P.-V.: Você teve o desejo de fazer máscaras porque estava intrigado por este objeto enquanto artista plástico. Havia também a vontade de fazer um teatro diferente?

E. S.: Era pelos dois motivos ao mesmo tempo. Com vinte anos, eu não sabia em qual direção ir. Amava muito a pintura, já havia inclusive feito algumas exposições... e num determinado momento, quis até mesmo ser músico. Mas era preciso escolher. Rapidamente percebi que era impossível ganhar a vida fazendo máscaras. Durante muito tempo, fiz cenários e faz apenas oito anos que eu consigo viver exclusivamente da fabricação de máscaras. Muitas vezes me disseram que eu havia inventado uma nova profissão. Jacques Lecoq sempre me encorajou a seguir essa via e eu sempre Ihe mostrava as máscaras que fazia. Mas foram apenas alguns anos antes de sua morte que elas começaram a ser utilizadas na Escola.

B. P.-V: Você já utilizou suas máscaras?

E. S.: Jamais tive o desejo de usá-las, mas eu as experimento em frente a um espelho. Se sinto que uma máscara não funciona em mim, é porque ela é ruim. Não as uso verdadeiramente, simplesmente faço algumas experiências.

\section{O verdadeiro começo: L'Age d'or}

E. S.: Minhas primeiras criações foram apenas um prelúdio. Um dia, quando estava viajando pela África, soube que alguém do Théâtre $d u$ Soleil tentava me contatar. Na época, eu não conhecia essa companhia. Quando voltei à França, a trupe encenava La 
Cuisine no Cirque Montmartre e encontrei Ariane, que me pediu algumas máscaras para trabalhar com os atores. Propus então algumas máscaras da commedia dell'arte, seis ou sete, que eu já havia fabricado. Em seguida, ela me propôs a criação dos figurinos para "Sonho de uma Noite de Verão," em 1968. Porém, nossa verdadeira parceria começou em L'Age d'or. Partimos de um trabalho sobre a commedia dell'arte, pois pretendíamos fazer um espetáculo sobre a atualidade. Uma verdadeira commedia dell'arte moderna. Como os quatro principais personagens desse teatro eram insuficientes nos dias de hoje, tivemos que inventar outros. Criei então novas máscaras inspiradas nessa tradição.

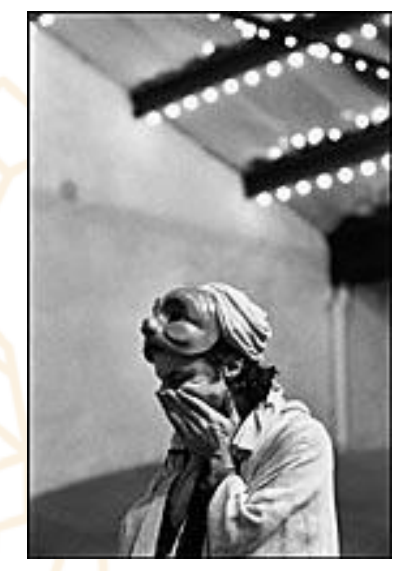

L'Age d'or

B.P.-V.: Qual material você utilizou para fabricá-las?

E.S. : Primeiro, o papier mâché, depois, o couro - que é uma técnica muito difícil de utilizar. Eu trabalhava em uma cabana, numa oficina de marcenaria, dentro da qual ia pendurando as máscaras, aos poucos. Os atores eram livres para escolher as máscaras que desejavam e Ariane não interferia. Na época, ninguém sabia como interpretá-las e eu mesmo ainda não sabia o que era verdadeiramente uma máscara de teatro. Eu me surpreendia constantemente ao ver que os atores não escolhiam necessariamente aquelas que eu considerava melhores em termos plásticos. Eu me dei conta de que eles eram sensíveis a outras coisas e que algumas "belas máscaras" não funcionavam em cena: elas não tinham uma leitura imediata e nem existência própria. Outras, menos adequadas em termos estéticos, faziam muito mais sucesso, pois tinham em si uma verdade de outra natureza. Podemos dizer que algumas máscaras são "mortas" e outras são "vivas." Em uma dezena de máscaras que eu fabricava, havia talvez duas que funcionavam e, por meio delas, reconhecíamos alguém.

B.P.-V.: Você encontrou uma explicação lógica para isso? 
E.S.: Ainda hoje, considero muito difícil dar uma explicação clara e racional. Porém, cada vez mais chego a sentir a melhor utilização de uma máscara. Descobri as coisas de maneira empírica, mas não tenho certeza de nada. Hoje, cometo menos erros, não faço mais uma máscara que não funciona, ou se isso acontece, ela não sai da oficina. Diversas vezes, me pediram para reutilizar aquelas que eu considerava ruins, mas uma máscara ruim não serve estritamente para nada.

\section{O aprendizado do trabalho com o couro}

B. P.-V.: Onde você aprendeu as técnicas do trabalho com o couro?

E. S. : Eu as aprendi sozinho, fazendo experimentos. Amelto Sartori trabalhava com a madeira, o gesso e o couro. Ele também deve ter encontrado suas próprias técnicas.

B. P.-V.: Ele não te transmitiu nada?

E. S.: Não, nunca o procurei. Acho que ele não teria nem mesmo aberto sua porta e eu não ousaria incomodá-lo, porque sabia que era alguém muito inacessível. Esse homem era um escultor muito solitário. Ele havia criado máscaras para Giorgio Strehler e Jean-Louis Barrault. Eu trabalhava sozinho, tateava. Um dia fui a um fabricante de couro com uma das minhas máscaras neutras, para me informar sobre as técnicas que ele empregava para dar forma ao couro. Ele ficou impressionado com meu trabalho e, finalmente, foi ele que quis saber como eu fazia. Hoje, é uma técnica que domino perfeitamente: sei como dar forma ao couro e sem danificá-lo. Porém, esse aprendizado me exigiu anos de trabalho. As antigas máscaras italianas eram feitas rusticamente, com o couro natural. Na commedia dell'arte, a visão do personagem era traduzida, sobretudo, através do figurino, mais do que pelo rosto. Os olhos eram muito pouco visíveis através da máscara. As máscaras do Arlequim eram todas pretas. Alguns dizem que isso era porque ele era um servidor vindo da África. Eu me questionei durante muito tempo a respeito dessa cor, pois ela não é cênica. Fabriquei máscaras de Arlequins vermelhas e também marrons e pretas. Em sua origem, as máscaras do Polichinelo e Patalone também eram pretas. Seria uma maneira de apagar o rosto?

B. P.-V.: Você então elaborou técnicas mais sofisticadas que aquelas da tradição commedia dell'arte?

E. S.: Acredito que as máscaras da commedia não eram muito "trabalhadas". Imagino que elas eram feitas por sapateiros ou pelos atores, e não por artistas ou artesãos, como é a tradição nos países da Ásia. Na época, me parece que as pessoas que 
fabricavam as máscaras não podiam dedicar todo o seu tempo a isso. Contudo, essas técnicas exigem muito. Hoje, somos poucos a obter tais resultados; creio que se trata de um verdadeira proeza técnica. Muitos não têm coragem nem paciência de fazer as necessárias e últimas finalizações. Os aprendizes que trabalham comigo às vezes se afobam diante de um pedaço de couro que resiste a eles. Eu lhes digo que devemos ser pacientes, que depois de uma dezena de horas de trabalho eles irão avançar.

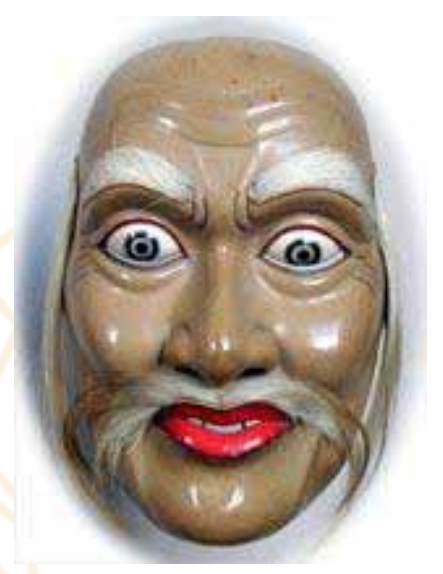

Topeng tua, máscara balinesa

\section{Primeiro encontro com as máscaras balinesas}

B. P.-V.: O seu gosto pela máscara se desenvolveu primeiro por meio da commedia dell'arte e depois você encontrou as máscaras vindas da Ásia. Esse encontro está ligado ao Théâtre du Soleil?

E. S.: Acho que sem esse encontro com as máscaras asiáticas, eu não faria máscaras hoje... Durante os ensaios de L'Age d'or, uma trupe balinesa se preparava para se apresentar em Paris, com um ator extraordinário - Pugra² ${ }^{2}$ que é quase um mito em Bali. Essa vinda aconteceu graças a Sadorno ${ }^{3}$, que queria provocar um encontro com o Ocidente. Um amigo conhecia essa trupe e propôs um encontro. Fomos todos nós, levando conosco uma mala cheia de máscaras que eu havia fabricado. Pugra olhou as máscaras, pegou a do Pantalone, colocou-a e começou a jogar com esse personagem. Ele não conhecia nada desta máscara, não conhecia também minhas máscaras e nem mesmo nossa civilização. Foi extraordinário. Os atores da sua trupe colocaram suas próprias máscaras, outros pegaram as minhas e eles se lançaram numa improvisação muito impressionante. Diante disso, Ariane ofereceu a

\footnotetext{
${ }^{2}$ Pugra foi um dos maiores atores-dançarinos de Bali. Ele morreu há alguns anos.

${ }^{3}$ Sadorno é um dançarino e diretor balinês. Ele foi um dos primeiros a querer "modernizar" o teatro balinês e a buscar contatos com o Ocidente. Ainda hoje, ele é professor.
} 
máscara de Pantalone a Pugra. Foi somente bem mais tarde que nós conseguimos considerar o fato de que máscaras de origens diferentes poderiam funcionar juntas.

Suas máscaras e seu jogo me fascinaram tanto que eu roubei algumas ideias. A máscara de Max, que criei para L’Age d'or, foi um pouco inspirada em uma máscara balinesa, da qual eu ainda me recordo muito bem, com os seus olhos profundos e bochechas grandes e vermelhas. Eu ainda não havia ousado utilizar este tipo de cor e esta máscara me incitou a fazê-lo. Ela se parece com a máscara Pandapa ${ }^{4}$ com a qual trabalhamos mais tarde no Théâtre du Soleil.

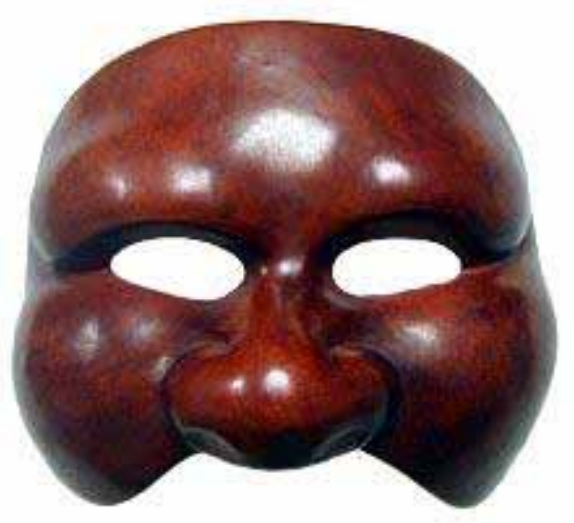

Máscara de Max

B. P.-V.: Existem outras máscaras do L'Age d'or que têm essa marca do Oriente?

E. S.: Não, ela é a única. Depois de encontrar esta trupe, retornamos aos ensaios de L'Age d'or e às máscaras da commedia dell'arte. Mantive contato com eles e me tornei amigo de dois dos atores que ficaram na França. São eles que me iniciaram. Eles me contaram coisas magníficas que eu nunca havia ouvido falar antes. Durante suas apresentações, pude ir às coxias, mesmo com o olhar desconfiado dos atores, que não entendiam muito bem porque eu queria assistir àquilo. Foi nessa ocasião que pude observar, pela primeira vez, um ator lavar o seu rosto antes de atuar e o seu ritual com as flores e as oferendas. Foram gestos simbólicos que me marcaram profundamente.

\section{Ousar trabalhar com máscaras de uma tradição que não nos pertence}

E. S.: Eu observava tudo isso de longe e Ariane também tinha muito pudor no início. Na época, nenhum ator francês havia ido a Bali aprender a dança; nenhum ator se interessava por essas máscaras, nós nem imaginávamos utilizá-las. Esse "clic" veio

\footnotetext{
${ }^{4}$ Máscara Bondrès (personagem do povo), batizada como "Pandapa" pelos atores do Théâtre du Soleil.
} 
muito mais tarde. Porém, eu estava certo de que havia alguma coisa de essencial nessas máscaras. Mais tarde, descobri uma galeria onde eram vendidos objetos balineses, entre os quais encontrei duas máscaras que me interessaram como documentos e foram as primeiras da minha coleção. Eram máscaras de madeira, recobertas de cera, visivelmente destinadas aos turistas, que eu decapei e repintei. Em outra galeria, encontrei um cesto cheio de máscaras, algumas em pedaços. Na época, elas não valiam quase nada. Eu acreditava que nós não tínhamos o direito de usar máscaras balinesas pelo fato de pertencerem a um teatro sagrado, que não é o nosso.

Um dia, porém, ousei levar algumas ao Théâtre du Soleil para que os atores as experimentassem. Rapidamente, entendemos que não poderíamos manipulá-las de qualquer maneira, que precisávamos respeitá-las. Eu me lembro que na mesma época, durante o Festival de Avignon, me pediram para participar de um evento organizado sobre máscaras de origens diversas. Aceitei, com a condição de que meus amigos balineses viessem com suas próprias máscaras. Durante essa oficina, pela primeira vez, atores franceses trabalharam ao mesmo tempo com máscaras da commedia dell'arte e com máscaras balinesas, antes mesmo de trabalharmos dessa maneira no Soleil.

Outro encontro importante para mim aconteceu alguns anos mais tarde, em Paris, com I Made Djimat, um grande ator balinês que me mostrou suas máscaras e continuou minha iniciação.

\section{Aprender copiando máscaras extraordinárias}

E.S: Durante anos, e ainda hoje, essas poucas máscaras levadas ao Soleil fizeram nosso aprendizado. Acrescentamos outras da minha coleção e então comecei a refazê-las, porque eu disputava sua possessão com Ariane! Ousei fazer cópias de máscaras que eu havia encontrado e que estavam em péssimo estado, mas cujo formato era bom. Também pedi emprestado a dois atores balineses e a I Made Djimat ${ }^{5}$ suas máscaras para que eu pudesse copiá-las. Foi preciso ganhar a confiança, pois de outra forma, eles não teriam nem mesmo me autorizado a tocá-las.

Tive a mesma experiência no Japão, onde certamente fui uma das poucas pessoas a ter autorização para copiar algumas máscaras. Algumas delas eu nunca mostrei à

\footnotetext{
${ }^{5}$ I Made Djimat nasceu em Batuan, em 1947. Ele é filho da grande dançarina Ni Ketut Cenik. Mestre de Topeng, ele é também um dançarino virtuoso de outras danças balinesas (Gambuh, Calon Arang, Baris, Djauk, etc). Ele se apresentou no Théâtre du Soleil em 1993, em parceria com o ARTA, onde ele ainda ministra estágios regularmente. Ele apresentou Calonarang, com sua trupe Panti Pusaka Budaya Group, no $9^{\circ}$ Festival de l'Imaginaire, no Théâtre du Soleil.
} 
Ariane porque ela teria vontade de utilizá-las. Ao mesmo tempo, eu tinha um pacto com o ator, pelo qual ele seria o único a poder utilizá-las. Assim, fiz minha aprendizagem, copiando máscaras extraordinárias. Com três ou quatro, tive um choque revelador.

B.P.-V.: Todas essas máscaras eram de madeira. Você se reencontrava então com a sua vocação primeira de escultor? É uma técnica muito diferente do couro?

E. S.: Esculpir máscaras de madeira é como esculpir a carne. As modelagens são mais macias.

B. P.-V.: Você realizou uma aprendizagem longa e paciente, entrando em um mundo secreto e sagrado.

E. S.: Para mim, com certeza este é um mundo sagrado. Nunca dediquei uma oferenda a uma máscara, mas não a deixo virada, nem a penduro na parede. Tenho o meu próprio ritual. Para um balinês, a máscara é um ser vivo, ela praticamente se move. Lá, uma árvore é escolhida para esculpir cada máscara.

B. P.-V.: Em seguida, você foi a Bali. Você viu Pugra novamente?

E. S.: Infelizmente não, porque ele já havia falecido. Demorei muito tempo para ir a Bali, pois queria ir como ator e não como turista. Quando fui, foi I Made Djimat que me levou aos templos e me mostrou como ele se preparava. Encontrei muitas respostas às questões que eu me colocava desde muito tempo. Evolui no trabalho da máscara e também no jogo.

Por que uma máscara é viva ou morta? Eu me dei conta que existem algumas máscaras que funcionam estando simplesmente postas sobre o rosto de um ator, sem que ele nem mesmo precise se mexer. Diante de objetos magníficos, que são quase enigmas, percebi a importância e a profundidade da máscara em geral. Nas máscaras balinesas existe uma verdade muito profunda que não encontramos nas máscaras ocidentais.

\section{O encontro com as máscaras japonesas}

B. P.-V: Quando você se interessou pelas máscaras japonesas?

E. S.: Meu primeiro encontro com Hideo Kanze, no Japão, se deu muito antes da minha viagem a Bali. Quando fui a esse pais e pedi para ver máscaras de Noh me disseram que isso não era possível.

Foi graças a Issey Miyake, o grande estilista que eu havia conhecido quando criei máscaras para Maurice Béjar ${ }^{6}$, que pude encontrar a família Kanze, com a qual ele mantinha relações privilegiadas. Como estrangeiro, eu não podia me dirigir sozinho a

\footnotetext{
${ }^{6}$ Por ocasião do espetáculo em homenagem à Maria Callas, dirigido por Maurice Béjart, Casta Diva, apresentado
} no IRCAM, em 1980. 
esta família e pedir para ver suas máscaras. Ainda hoje, praticamente nenhum estrangeiro pode fazê-lo. Durante minha primeira visita, acompanhado por Issey Miyake, Hideo Kanze me mostrou três máscaras.

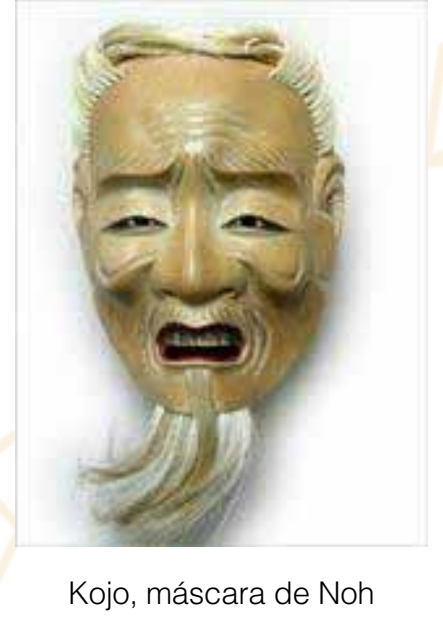

Isso para mim foi um acontecimento. Ele estava ao meu lado, tirando cada máscara da caixa na qual se encontrava e mostrando para mim. Não houve discussão. Em seguida, ele as guardou e nós tomamos um chá. Perguntei então se eu poderia ver outras máscaras. Ele me disse: "Sim, em três semanas. Eu voltei a Tokyo. Não tinha muito dinheiro, e ficar ainda três semanas naquela cidade iria me custar uma fortuna. Porém, rapidamente entendi que se tratava de um teste.

B. P.-V.: Você esperou as três semanas?

E. S. : Claro. Hideo sentiu então que podíamos começar uma relação. Na época, ele era um dos poucos atores japoneses abertos ao Ocidente: ele já havia encontrado Jean-Louis Barrault e então aproveitei essa abertura. Hoje, posso ir a qualquer teatro em Tokyo, que sou acolhido de braços abertos. Escalei a pirâmide. Nesta época, refazer ou utilizar essas máscaras estava fora de cogitação para mim. Vê-las, já foi um grande choque, pois me parecia impossível que tais objetos pudessem ser feitos. Eu já havia visto algumas máscaras em museus de Paris, mas elas eram apenas cópias "vagas". São poucos os Ocidentais que viram máscaras japonesas originais do século XV.

B. P.-V.: Ainda hoje, é difícil para um ocidental ver essas máscaras originais?

E. S.: É impossível, caso não conheça as pessoas a quem elas pertençam. Pouco a pouco, durante minhas viagens, pude ver todas as máscaras originais do Japão. Fui ao museu de Nara, onde se encontram as máscaras de Gigaku, e também aos templos. Escavei por todos os lados, para alimentar meu trabalho. Três anos atrás, em Kyoto, tive a oportunidade de ver as máscaras magníficas da família Kongo, entre elas, 
as do escultor Shakuzuru, que datam do século XV. Eu estava acompanhado pelos atores que costumam trabalhar com Kongo e que nunca ousaram pedir para ver as máscaras que ele me mostrou. Algumas só podemos ver no palco. São obras-primas, tesouros nacionais catalogados, que não podem nem mesmo sair do país.

Também conheci Kiyokazu Kanze, o chefe de todo o "sistema" do Noh (iemoto), que me autorizou a ver algumas de suas máscaras. Nesses últimos tempos, pude copiar a mais linda máscara de kyôgen que existe, uma máscara antiga que não pode ser utilizada porque se tornou muito frágil. Eu a copiei para mim, e para agradecer a família de atores, eu Ihes ofereci uma outra cópia. Quando o chefe da família recebeu a máscara, ele disse que era preciso utilizá-la imediatamente para que ela se tornasse "viva". Essa máscara, na qual eu assinei meu nome em japonês, desde então faz parte da coleção da família.

B. P.-V.: Nas máscaras balinesas existem signos rituais que o escultor acrescenta quando a máscara é finalizada. Acontece o mesmo no Japão?

E. S.: No Japão, é acrescentada somente a assinatura. Em outros tempos, as máscaras não eram nem mesmo assinadas.

B. P.-V.: O fato da sua máscara ter sido integrada à coleção dessa família é um reconhecimento supremo. O seu percurso é excepcional. Você deseja transmitir todo esse saber que adquiriu?

E. S.: É um percurso que fui obrigado a fazer sozinho, mas que sempre esteve relacionado com o Théâtre du Soleil. Recebi o titulo de Maître d'art' a alguns anos atrás e então me perguntei sobre a questão da transmissão. Geralmente, as pessoas vêm me ver com a ideia de aprender rapidamente uma técnica e isso não me interessa. Sim, gostaria de transmitir e de talvez escrever um livro.

B. P.-V.: Mais que o percurso de aprendizagem, podemos falar de uma trajetória iniciação. Você passou por certo número de etapas, foi testado, para em seguida ser acolhido e hoje é totalmente reconhecido.

E. S.: Para mim também era importante contribuir com a apresentação desse tipo de teatro, no qual a máscara é indispensável, na Europa. Convidei então lemoto Kiokazu Kanze para apresentar o Noh na Villette ${ }^{8}$. Este grande artista que raramente sai de seu país - onde ele se apresenta praticamente todos os dias - aceitou vir a Paris em função das boas relações que temos. Na França, que eu conheça, existe

\footnotetext{
${ }^{7}$ Erhard Stiefel foi nomeado Maître d'art pelo Ministério da Cultura e da Comunicação francês, em 2000.

${ }^{8}$ Dentro da programação do Festival d'Automme, em 1997.
} 
apenas uma sala de Noh, nos arredores de Aix-en-Provence. Para que os atores fossem acolhidos corretamente, construí um verdadeiro palco de Noh, desmontável, pois fazia questão de que as apresentações ocorressem nas mesmas condições que no Japão.

B. P.-V.: Você considera ter tido mestres entre estas pessoas que encontrou no Japão?

E. S.: Encontrei um escultor de máscaras, um "tesouro vivo", que faz objetos magníficos, mas que praticamente nunca são utilizados por atores. Cada família de atores utiliza suas próprias máscaras, transmitidas de geração a geração. Então, meus mestres são os atores, pois foram eles que me mostraram seus tesouros: as máscaras da origem que se chamam Hon Men. Todas as outras máscaras do Noh são cópias destas. No Japão, a arte da cópia não tem uma conotação pejorativa como no Ocidente. É uma maneira de perpetuar uma tradição. Por exemplo, todos os escultores que fazem uma máscara Komote se apoiam no modelo fabricado por Tatsuyemon, no século XIV. Evidentemente, ninguém consegue alcançar o nível deste artista, mas é dito que devemos ir sempre "em direção ao alto" para poder fabricar uma máscara.

B. P.-V.: Isto se assemelha a uma experiência espiritual?

E. S.: Não sei. A ideia de ir "em direção ao alto" é também uma noção presente no Noh. Mas "o alto" não significa necessariamente "o céu". É a ideia de superar a si mesmo.

B. P.-V.: Eu li que, para você, contemplar essas obras primas incitava emoções tão fortes quanto aquelas que você sente diante de um quadro de Goya.

E. S.: Para mim é a mesma emoção. Uma máscara é uma obra de arte - o que nunca foi admitido no Ocidente. Aqui, ela é um objeto curioso, folclórico, enquanto que em Bali ou no Japão, ela é assimilada a outras formas de escultura. O que é extraordinário em uma máscara é que ela só encontra o seu fim quando é interpretada por um ator. É nesse momento que ela "acorda" No Japão, é dito que a máscara tirada do rosto é terasu, "adormecida". Ela pode também estar "adormecida” em cena, quando um ator que a utiliza se coloca em certa posição e inclina a máscara para baixo. Claro, o ator está sempre presente com sua máscara, mas ele da a impressão de se retirar para ceder seu lugar a outro ator. Também se diz que a máscara pode ser "nublada" (kumorasu), ou "se iluminar". Por que as máscaras nos fascinam e nos provocam emoções tão fortes? Podemos imaginar que, antigamente, quando fotos e filmes não existiam, as máscaras de Noh tinham uma dimensão diferente da que existe hoje. Elas poderiam se confundidas com espectros, com fantasmas. Em Bali, ainda hoje, as máscaras causam medo. Acontecia dos atores passarem uma noite no cemitério com 
sua máscara, antes de interpretá-la. No Japão, ainda se conta que certas máscaras, por serem muito poderosas, deixaram atores loucos.

\section{No Théâtre du Soleil: se alimentar de máscaras de tradições orientais.}

B. P.-V.: Voltemos ao Théâtre du Soleil. Para Les Sheakespeare, você fez máscaras inspiradas no Japão, mas que não são cópias fieis. Ariane diz que ela nunca procurou fazer uma cópia do teatro oriental. Ela criou seu próprio Oriente. Você fez o mesmo tipo de caminho?

E. S.: $\mathrm{Na}$ época em que trabalhávamos sobre as peças de Sheakespeare, eu tinha visto apenas algumas máscaras japonesas que Hideo Kanze me mostrou e que eu não havia ousado copiar. Foi apenas bem mais tarde que fiz minha primeira cópia, mas sempre a escondi. Eu ainda nem mesmo a pintei. Naquela época, procurávamos o nosso próprio Oriente, que se situava em alguma parte entre Bali e o Japão. Eu tinha necessidade de me alimentar de máscaras pertencentes a outras tradições. Então me apropriei de alguns traços de máscaras japonesas, mas era fora de cogitação fazer máscaras de Noh.

B. P.-V.: Quais foram as reações dos japoneses quando viram os espetáculos?

E. S. : Alguns, que conheciam bem o teatro Noh, ficaram surpresos e muito interessados. Para eles, esses espetáculos eram quase uma revelação sobre sua própria cultura. Os japoneses achavam nosso trabalho bonito e justo, e não ficaram chocados pelo fato de nos apropriarmos de certos elementos de sua cultura.

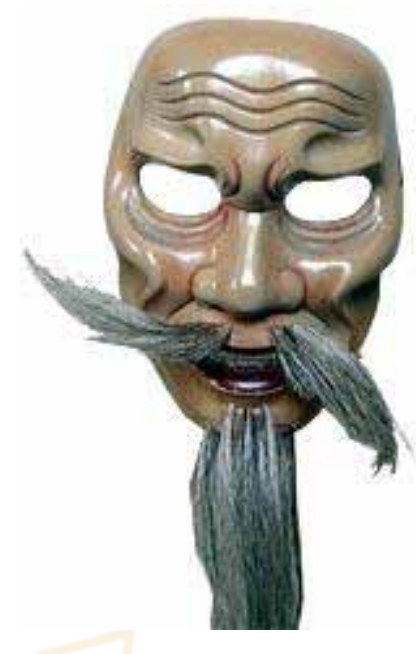

Máscara de Henry IV

B. P.-V.: Para l'Histoire terrible mais inachevée de Norodom Sihanouk, você fez cópias de máscaras balinesas. 
E. S.: Na verdade, não eram cópias exatas. Em Bali existem personagens-tipo, mas cada escultor propõe sua versão da máscara. Diferentemente das máscaras do Japão, que devem ser cópias exatas, as balinesas estão em constante evolução, e nem sempre no bom sentido. Creio que a tradição deles corre o risco de se perder. Para voltar ao Théâtre du Soleil, é preciso pontuar que, mesmo se existirem poucas ou nenhuma máscara em cena, todos os atores trabalham com elas durante os ensaios. Se uma máscara não é justificável, ela não permanece no espetáculo. Mas se ela é necessária, então a mantemos. Nas peças de Sheakespeare, o jovem ator que interpretava Henry IV, o papel de um velho, precisava de uma máscara. Em Sihanouk, o pai do mesmo era um espectro. Como trazer ao palco alguém que já está no além? Também, neste caso, a máscara nos parecia absolutamente necessária. No início, é verdade, eu ficava um pouco frustrado com o fato de não haver tantas máscaras em cena, quantas eu havia desejado. Mas confeccionar máscaras exige muito tempo. Durante os ensaios, não posso estar mais adiantado que os atores; às vezes, mal posso segui-los.

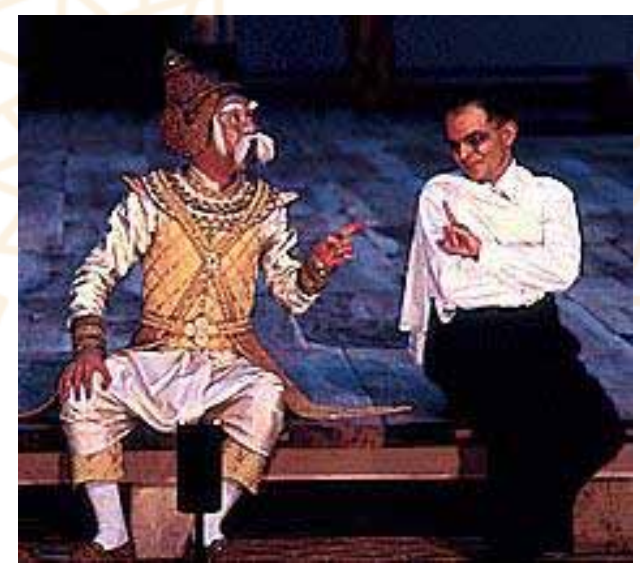

Sihanouk

B. P.-V.: Todas as máscaras utilizadas nos ensaios estão arquivadas aqui?

E. S.: Existe certo número de máscaras que ficam aqui, no Théâtre du Soleil. E existem algumas que eu pego, mas que Ariane me pede de volta logo em seguida. Fiz cópias das máscaras que melhor funcionam: há duas máscaras de Pandapa, duas do Rajistan ${ }^{9}$, três Arlerquins, dois Pantalones. É preciso que eu as reproduza ainda mais.

B. P.-V.: Então, foi apenas por Et soudain des nuits d'éveil que você confeccionou verdadeiramente cópias. Como foi o seu procedimento?

${ }^{9}$ Máscara balinesa batizada "Rajistan" pelos atores do Théâtre du Soleil. 
E. S.: Trabalhei a partir de numerosos documentos que eu possuía. Fiz três croquis a partir de máscaras encontradas em algumas coleções. Queria que a verdade de sua origem existisse nessas máscaras.

B. P.-V.: Os tibetanos que vieram se apresentar no Théâtre du Soleil as viram?

E. S.: Dois monges importantes e muito bons juízes vieram um dia na minha oficina e ficaram surpresos ao ver que alguém que não era tibetano pudesse fazer essas máscaras. Quanto a mim, fiquei surpreso pelo fato deles concordarem. Realmente, tratava-se de verdadeiras cópias. Eu me dei conta de que podia fazer máscaras de outros. Eu me senti cada vez mais livre; me apropriei de elementos porque sou um ladrão de ideias, de linhas, de formas, de cores. Como todos os artistas!

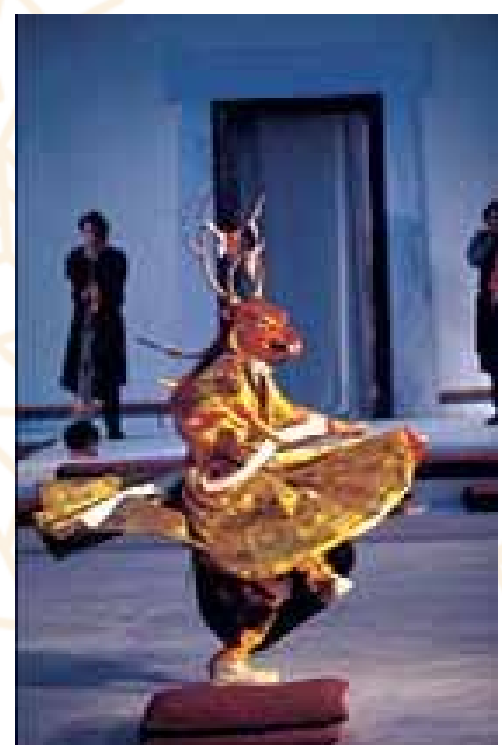

Et soudain des nuits d'éveil

\section{A maquiagem não é uma máscara}

B. P.-V.: Em Les Atrides são as maquiagens que dominam. Você interfere nessa pesquisa?

E. S.: Não. Alguns atores vêm, às vezes, me perguntar o que acho de suas proposições, mas não digo jamais como fazer. Prefiro que eles desenvolvam essa pesquisa entre eles. Quando um ator encontra uma ideia que funciona, os outros a repetem e a maquiagem progride. Tomo cuidado para não dar muitas indicações; simplesmente, confirmo as pistas que eles descobriram sozinhos. 


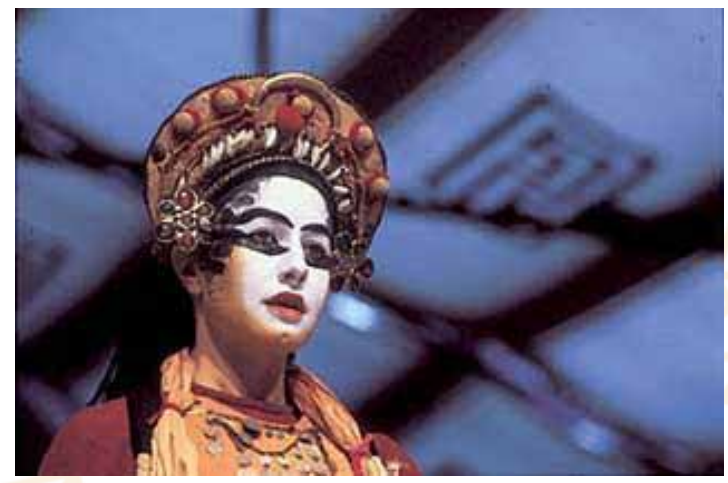

Iphigénie à Aulis

B. P.-V.: Qual é a relação entre a máscara e a maquiagem?

E. S.: Para mim, a maquiagem não é uma máscara. É um rosto sobre o qual há signos que transformam o ator, é verdade. Na Ópera de Pekin, as maquiagens são inspiradas em máscaras. É o que tentamos fazer aqui, algumas vezes.

\section{A pesquisa de uma máscara flexível}

B. P.-V.: Em Tambours sur la digue, estamos entre a máscara e a maquiagem.

E. S.: Há muito tempo, Ariane vem se perguntando como prosseguir essa pesquisa. Ela pensa numa máscara flexível, que representaria um rosto verdadeiro, próximo da realidade, sem uma transposição verdadeira. Para Tambours sur la digue, nós nos aventuramos nessa direção. Contudo, participei pouco da criação, pois é uma trilha na qual não tenho mestria no momento. Como conseguir essa flexibilidade? Para mim, uma máscara é rígida e é isso que é formidável, pois uma vez funcionando no rosto do ator, ela perde essa rigidez e torna-se verdadeiramente animada. Uma vez vestida, a máscara se mexe, mesmo se ela for de madeira. Para mim, uma máscara é um objeto em si, eu não fui além disso. Portanto, adoraria ir em direção ao que propõe Ariane, pois é um tipo de desafio. Tentei criar pedaços de rostos, pedaços de testas, de narizes, de queixos...

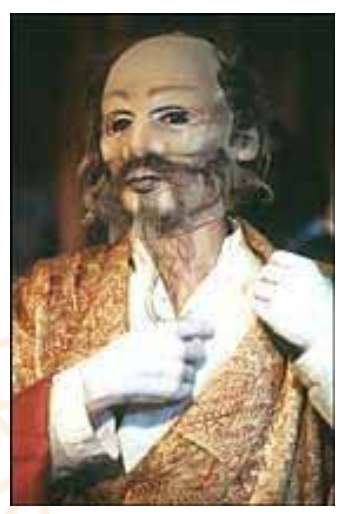

Tambours sur la digue 
B. P.-V.: Mathias Langhoff tentou fazer um trabalho desse tipo com pedaços de rostos adicionados. Mas se trata de rostos feridos, da pesquisa de um efeito "grande-fantoche".

E. S.: Eu procuro pedaços de máscaras que transformem, mas que continuem anatomicamente juntos, em harmonia com o resto do corpo; que sejam um tipo de acréscimo quase invisível. Neste momento, faço experimentos sobre a flexibilidade, com um jovem ator do Théâtre du Soleil que fabrica narizes falsos para o Le Dernier Caravansérail. É o início de uma máscara flexível. Procuro uma máscara que seja quase como uma luva, mas ainda não a encontrei.

B. P.-V.: O Soleil se aproximou disso em Tambours sur la digue: os atores utilizavam tecidos revestidos de algodão, maquiados sobre seus próprios rostos.

E. S.: A questão que me preocupa é a seguinte: uma máscara deve ser expressiva por ela mesma ou somente quando ela é colocada sobre um corpo? Em uma marionete, a cólera não esta inscrita no rosto, mas no corpo. É esse último que dá a expressão.

B. P.-V.: O movimento torna a máscara expressiva. Em Tambours sur la digue, o rosto devia estar impassível, mas as mãos também eram como de madeira.

E. S.: Nesse espetáculo, o olhar do espectador ia do corpo ao rosto. Em um teatro de máscaras, olhamos apenas para ela, mesmo se o figurino a acompanha.

\section{Permitir a liberdade do rosto verdadeiro}

B. P.-V. : No teatro Noh, o rosto transborda a máscara, como se ela não fosse adaptada a ele.

E. S.: Não é o que procuramos no Théâtre do Soleil, mas eu gosto muito desta ideia. Hideo Kanze me falava sobre isso como "choque dramático": a carne se fere em algo rígido. A emoção sai por sua carne verdadeira e não pela máscara. Um ator balinês me disse um dia que não se deveria esconder completamente o rosto do ator, pois isso impediria a energia de sair. E realmente, ele não suportava algumas máscaras muito completas. Para ele, é essencial permitir a liberdade ao rosto verdadeiro.

B. P.-V. : O que você buscava quando realizou as máscaras articuladas para Les Shakespeare ? Você adaptou a tradição ao jogo dos atores do Théâtre du Soleil ?

E. S.: Jacques Lecoq dizia que não deveríamos falar com uma máscara inteira, pois ela cobre a voz do ator. Quando fui ao Japão, porém, me dei conta de que todos os atores falavam atrás de uma máscara inteira. No Théâtre du Soleil, nós não querí- 
amos trabalhar nem com máscaras inteiras, nem com meias-máscaras. Decidi então, articular as máscaras inteiras: eu as serrei em duas partes e as liguei com elásticos.

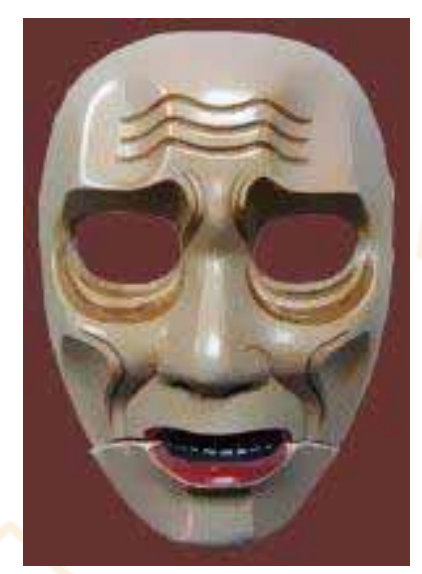

Máscara da Duquesa de York

\section{Máscaras que vão da cabeça aos pés}

B. P.-V.: Em L'Indiade, havia o urso Moona Baloo e em Et soudain des nuits d'éveil um yak. Vocês falam deles como verdadeiras máscaras.

E. S.: Para mim, nos dois casos se trata de uma "máscara total". Na África, a palavra máscara designa, ao mesmo tempo, o que é vestido sobre o rosto e sobre o corpo, os dois são inseparáveis.

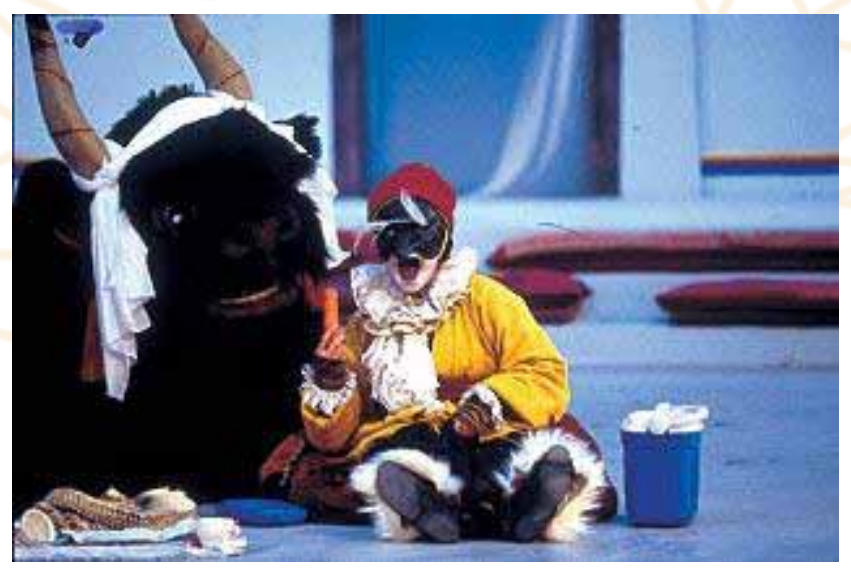

Et soudain des nuits d'éveil

Ariane Mnouchkine: Realmente, são máscaras que vão da cabeça aos pés. Os ursos eram muito realistas. Um dia, no final de uma apresentação, um espectador veio me ver muito bravo, convencido de que se tratava de um animal verdadeiro, e de que nós não dávamos conta do perigo. Eu fiquei maravilhada. 


\section{A máscara pode ser um guia}

B. P.-V.: Ariane, você fala sempre que a máscara pode ser um guia.

A. M.: É um guia, sim. Para mim, uma máscara verdadeira é um objeto mágico, "feiticeiro", um objeto de encarnação. Se você o escuta, ele te guia em sua direção. É um professor. É um personagem que, se você o escuta bem, pode ser seu mestre. $\mathrm{Na}$ entrevista com Hélène, nós evocamos o narcisismo do ator. Acho que um ator que deseja que o seu "eu" continue a existir atrás da máscara está perdido. Ele vai fazer mal a si próprio, vai sofrer demasiadamente, pois a máscara não Ihe permitirá ser ele mesmo. Ele pode, ao contrário, se dar o prazer supremo do ator que é o de se tornar um outro.

B. P.-V.: A palavra topeng em balinês significa "algo que esmaga o rosto". Seria algo que retira o "eu" do ator?

A. M.: É preciso desconfiar de algumas expressões que nem sempre são esclarecedoras. Por exemplo, a palavra francesa répétition (repetição) em relação à italiana prova (teste) me entristece. Em francês, nós falamos jouer (jogar) e em inglês to act (atuar), o que não é nada mal. Porém, em italiano é recitare (recitar), o que pode ser uma maldição para os atores italianos, pois é a pior recomendação que se pode dar a um ator!

B. P.-V. : Você se lembra do encontro de vocês com a trupe de teatro balinesa durante os ensaios de L'Age d'or?

A. M.: Nós ficamos realmente emocionados, mas talvez não verdadeiramente surpresos. Se não imaginássemos que aquilo pudesse funcionar, não teríamos nem mesmo proposto. Mais tarde, fui a Bali, onde encontrei um ator - Kakul. Ele era muito radical em comparação à Pugra e Sadorno que se abriram à Instituição em Denpasar e às temporadas no estrangeiro. Ele era tão grande quanto Pugra, mas não saía de seu vilarejo e se apresentava apenas nos templos. Passei três semanas vendo-o ensinar entre suas galinhas.

B. P.-V.: A quantos alunos ele ensinava?

A. M. : A poucos alunos, às vezes apenas um. A última vez em que fui a Bali, vi a sobrinha de I Made Djimat, Sekar, que ensinava a um ou dois alunos, mas nunca para uma turma muito grande.

B. P.-V.: Qual é a sua relação de trabalho com Erhard? Vocês se entendem sem se falar, como é com Jean-Jacques? 
A. M.: A relação não é a mesma porque, com Jean-Jacques passamos doze horas por dia juntos. O que não é o caso de Erhard, salvo alguns raros momentos. Erhard faz sua própria viagem no universo das máscaras, e de tempos em tempos, nós nos encontramos. Existem também os acasos. Ele nunca poderia fazer todas as máscaras que nós usamos em um espetáculo, porque sua fabricação exige muito tempo. Muitas vezes, felizmente, uma máscara que ele já criou entra no espetáculo, sem ter sido "percebida".

Hoje, eu me pergunto por que faz tanto tempo que deixei de lado as máscaras, se sempre tenho saudade de regressar a elas. Cada vez que as vejo, tenho vontade de visitá-las de novo. A máscara é presente no nosso trabalho, mas não aparece mais nos espetáculos porque estamos cada vez mais "no presente".

\section{Máscaras que poderíamos esquecer}

B. P.-V.: Você não as deixou verdadeiramente, salvo talvez em Le Dernier Caravansérail. Em Et soudain des nuits d'éveil, havia o yak, a máscara do cervo, as máscaras de Tashi Shölpa, assim como uma máscara de Pantalon. E depois, sobretudo em Tambours sur la digue, ainda havia máscaras.

A. M.: Sim, é verdade. Mas são máscaras de outra natureza. Começamos pensando que seriam máscaras duras, mas ao longo do trabalho, fui querendo um duro menos duro, mais fino, mais transparente. Se tivéssemos mantido as máscaras de madeira, as marionetes teriam sido realistas demais. Justamente porque a marionete é em madeira, nós precisávamos de uma "máscara de carne".

B. P.-V.: E essa "máscara de carne" nos parecia uma matéria dura, assim como as mãos dos atores, o que era emocionante.

A. M.: Já para Les Shakespeare eu queria que existissem máscaras, mas que não nos déssemos conta delas. O que acontecia: depois de um tempo, esquecíamos essas máscaras, que eram, portanto, de madeira. Isso pode se tornar um debate escolar: "porque colocar máscaras se é para esquecê-las". Acredito que é a cabeça que esquece a máscara, uma vez que o corpo não a esquece. A máscara torna o jogo sublime. O jovem ator que fez Henry IV nunca poderia tê-lo feito sem uma máscara.

B. P.-V.: Com uma maquiagem, teria sido uma caricatura?

A. M.: Não se trata de dizer que uma máscara é melhor que uma maquiagem, não é uma questão técnica. Uma máscara é uma tradução. Ela transporta a uma outra 
dimensão, ela transforma o espaço, o tempo. Talvez seja por isso que nós as utilizemos menos quando nossas peças estão "no presente".

\section{O teatro é a arte de fazer voltar os mortos}

B. P.-V.: A máscara permite também se questionar a vida e a morte em cena. É um dos temas essenciais de todo grande teatro. Você sente isso ou são temas que você não quer abordar? As culturas asiáticas que continuam a utilizar máscaras têm uma relação com a morte que, de nenhuma forma, é igual à nossa.

A. M.: O teatro é a arte que faz voltar os mortos, enquanto que o cinema é a arte de conservá-los. $O$ teatro permite que eles sejam reencarnados. Mas eu acredito que esse trabalho só é possível inconscientemente. Nós trabalhamos com a morte, porém como o trabalho de um agricultor, que dá vida novamente à terra e, em alguns meses, o que estava morto se torna vivo. No teatro, é a mesma coisa: um rei morto, sob um túmulo de pedra, vai se tornar vivo. Um herói nascido da cabeça de um autor vai se tornar vivo. Acho que podemos fazê-lo porque coexistimos com essa morte de maneira familiar, sem grande solenidade com o luto. Se nós começarmos a intelectualizar demais essa relação, já não é mais um trabalho de vida, mas uma constatação da morte. O teatro é a arte de reviver! O que está morto, está sempre revivendo e o que está vivo, morrendo. Estamos constantemente nesse caminho; vamos em direção à morte, mas já há outros que revivem o que nós fizemos.

\section{Uma verdadeira máscara não esconde, ela torna visível}

B. P.-V.: Os japoneses dizem que uma máscara "dorme" quando ela é retirada. Podemos ver a máscara como uma matéria inerte que, de repente, cria vida em cena graças à arte do escultor e do ator. É uma operação mágica, uma passagem da inércia à vida que causa uma emoção muito forte. É talvez a emoção mais forte que podemos sentir enquanto espectadores. Encontramos aqui a ideia de aparição: uma coisa que não existia, que estava morta ou em repouso, e que cria vida.

E. S.: É uma noção importante, essa da verdade: é sempre preciso que a máscara seja "verdadeira". Se não for o caso, o espectador sente imediatamente. É preciso que a emoção passe. Se a verdade não puder sair, não há emoção, nada é legível e nós ficamos "de fora". 
B. P.-V.: Falávamos agora mesmo da importância das palavras. Em francês, a palavra "máscara" dá a ideia de algo que esconde, porém, ao escutar vocês falarem, na verdade ela é aquilo que revela. Que palavra é empregada em japonês?

E. S.: A máscara de Noh é "o rosto que penduramos". O ator é considerado quase como uma "base." É verdade que um ator que acredita se esconder atrás de uma máscara se encontra na verdade nu e fraco, pois uma verdadeira máscara não esconde, ela torna visível.

Entrevista realizada por Béatrice Picon-Vallin no Théâtre du Soleil em 29 de fevereiro de 2004. 